\title{
Participacija otrok v razvezni mediaciji po Družinskem zakoniku
}

\author{
Od koncepta do implementacije
}

\begin{abstract}
Prispevek prekinterdisciplinarnega povezovanja teoretskih konceptov mediacije, socialnegadela in družinskega prava prikaževlogo otroka v mediaciji ob razvezistaršev. Mediacijskipostopekmora kljub svoji neformalni naravi zagotoviti primerljivo raven varstva pravice otrok do participacije, kot ga lahko otroci pričakujejo od formalnih družinskopravnih postopkov. Pomemben korak kutrditvi položaja otrokv mediaciji je bil v slovenskem prostoru dosežen leta 2017s sprejetjem Družinskega zakonika, ki mediatorju omogoča vključitevotroka v mediacijo. Ciljev participacije otrokv mediaciji je več: zagotavlja spoštovanje otrokove procesne pravice do izjave, omogoča raziskovanje otrokovega doživljanja razveze in spodbuja zaupno osebo, da krepi moč otroka. V prispevku sta ob upoštevanju slovenske normativne ureditve participativnih pravic otrok in mediacije predstavljena celovit koncept vključevanja otrok v mediacijo in njegova implementacija.
\end{abstract}

Ključne besede: otrok, udeležba, razveza, reševanje sporov, družinska mediacija, glas otroka.

Eva Jambrek, univerzitetna diplomirana socialna delavka, je družinska mediatorka pri Ministrstvu za delo, družino, socialne zadeve in enake možnosti ter zagovornica otrok pri Varuhu človekovih pravic RS. Je doktorska kandidatka Evropske pravne fakultete Nove univerze. Kontakt: jambrek. eva@gmail.com.

\section{Children's participation in divorce mediation under the Family Code - From concept to implementation}

The article analyses the role of a child in divorce mediation through disciplinary integration of the theoretical concepts of mediation, social work and family law. Despite its informal nature, the mediation process shall ensure a comparable protection level of children's right to participation as children can expect from formal family law proceedings. In Slovenia, an important step towards consolidating the position of children in mediation was achieved in 2017 with the adoption of the Family Code, which enables a mediatior to include a child in mediation. The participation of children in mediation pursues several goals: it ensures a child's right to express views freely, enables consultation with a child about their experiences of family separation and supports the empowerment of a child by a trusted person. The article presents a comprehensive concept of child inclusive mediation and its implementation, taking into account the Slovenian normative regulation of mediation and children's participatory rights.

Keywords: child, involvement, divorce, dispute resolution, family mediation, child's voice.

Eva Jambrek, BA in Social Work, is a family mediator at the Ministry of Labour, Family, Social Affairs and Equal Opportunities, and a children's advocate at the Human Rights Ombudsman of the Republic of Slovenia. She is a PhD candidate at the New University, European Faculty of Law. Contact: jambrek.eva@gmail.com.

\section{Uvod}

Spremembe družinskega življenja v zadnjih desetletjih se kažejo v pestrosti in raznovrstnosti družin, v katerih odraščajo otroci 21 . stoletja. Kljub značilnim spremembam, ki so vidne v povečevanju števila razvez, kohabitacij, enostarševskih in reorganiziranih družin, ostaja družina temeljna družbena institucija in najpomembnejša življenjska vrednota Slovenk in Slovencev (Švab, 2001, str. 62; Toš, 2016, str. 85). Čeprav so mnogovrstne intimne izbire staršev danes vse bolj destigmatizirane, niso zato nič preprostejše ali čustveno manj boleče (Folberg, Milne in Salem, 2004; Jensen, 2009, str. 140-155). Razveza staršev 
namreč še vedno ostaja eden najbolj stresnih življenjskih dogodkov in izkušnja vse več otrok (Andrejč, 2014, str. 25).

Mediacija v družinskih zadevah je v Družinskem zakoniku (2017) opredeljena kot postopek, $v$ katerem udeleženci ${ }^{1}$ prostovoljno s pomočjo ene ali več nevtralnih tretjih oseb (mediatorjev ${ }^{2}$ ) skušajo doseči mirno rešitev spora, ki izvira iz medsebojnih družinskih razmerij. Glede na drugi odstavek 205. člena Družinskega zakonika naj bi se mediacija izvajala predvsem pred začetkom sodnega postopka $\mathrm{z}$ namenom oblikovati predlog za sporazumno razvezo zakonske zveze ali predlog za sklenitev sodne poravnave o varstvu in vzgoji otroka, o njegovem preživljanju, o njegovih stikih s starši ali z drugimi osebami ali o vprašanjih izvajanja starševske skrbi, ki odločilno vplivajo na otrokov razvoj.Pravilnik o izvajanju predhodnega svetovanja (2019) v 9. členu zavezuje strokovnega delavca na centru za socialno delo, da v postopku predhodnega svetovanja stranke vedno seznani z namenom in postopkom mediacije. Ob soglasju zakoncev lahko center za socialno delo predhodno svetovanje nadaljuje $\mathrm{e}^{3} \mathrm{~s}$ postopkom mediacije ali pa se zakonca udeležita mediacije pri drugih izvajalcih.

Mediacija se je pokazala za učinkovito metodo reševanja družinskih sporov. Konfliktni partnerski odnos in morebitni dolgotrajni sodni postopki namreč pomenijo tveganje za otrokov zdrav psihosocialni razvoj in za njegovo uspešno prilagoditev na spremembe, ki jih povzroča razhod družinske skupnosti. Cilj mediacije kot metode reševanja družinskih sporov je predvsem izboljšati komunikacijo med družinskimi člani in spodbuditi starše k prevzemanju odgovornosti za odločanje o vprašanjih, ki so povezana z otroki (Roberts, 2008; Parkinson, 2011).

Ob zapisanem se mi porajajo vprašanja: ali slovenska normativna ureditev mediacije $v$ družinskih sporih dovolj varuje participativne pravice otrok ob razvezi staršev? Ali naj se otrokov glas v mediaciji uresničuje prek njegovih staršev ali pa naj otroka kot kompetentnega sogovornika povabimo v mediacijo? Kakšna je vloga mediatorja pri zagotavljanju za otroke prijazne udeležbe v mediaciji?

Participacijo otrok v razvezni mediaciji kot osrednji predmet raziskovanja obravnavam v kontekstu modela ekosistemske družinske mediacije, ki temelji na interdisciplinarnem povezovanju teoretskih konceptov mediacije, družinskega prava in socialnega dela (Parkinson, 2019). Vlogo in pristop mediatorja v razvezni mediaciji utemeljujem na podlagi prepleta transformativnega modela, ki je usmerjen v podporo pri komunikaciji, in evaluativnega modela, ki je usmerjen v sklenitev mediacijskega dogovora. Ker družinska mediacija posega na področje družinskopravnih razmerij, mora biti mediator dobro seznanjen z načeli in

$1 \quad V$ prispevku uporabljam tudi pravni termin stranka, kakor zakonski akti o mediaciji opredelijo formalnega udeleženca mediacije. Formalni udeleženec mediacije, v znanstveni literaturi se uveljavlja tudi sinonim mediant, je vsaka fizična oseba, ki ima poslovno sposobnost. Pomembno je dodati, da sodobna doktrina socialnega dela v procesih pomoči (pravni) termin stranka opušča in ga nadomešča z uporabnik, ekspert iz izkušenj, sogovornik, sopotnik oziroma sodelavec (Čačinovič Vogrinčič, 2010, str. 243).

2 V prispevku uporabljeni izrazi v moški slovnični obliki se uporabljajo kot spolno nevtralni.

3 Zaradi varovanja načela nepristranskosti in načela zaupnosti strokovni delavec centra za socialno delo, ki je sodeloval pri mediaciji, ne sme sodelovati pri izdelavi mnenja za sodišče v postopku za varstvo koristi otroka (peti odstavek 210. člena Družinskega zakonika). 
pravili družinskega prava, ki ureja prenehanje življenjske skupnosti partnerjev, razmerja med starši in otroki ter procesne pravice otrok $\mathrm{v}$ družinskopravnih postopkih (Novak, 2017). Pri analizi se zato opiram na koncepte, kot so: institut starševske skrbi, načelo participacije otrok, načelo otrokove največje koristi, koncept zagovorništva otrok. Mediator se lahko pri neposrednem vključevanju otroka v mediacijo opre tudi na nekatere teoretske koncepte socialnega dela, to so koncept delovnega odnosa, etika udeleženosti in perspektiva moči (Kodele in Mešl, 2013; Čačinovič Vogrinčič in Mešl, 2019).

$\mathrm{V}$ prvem delu prispevka na podlagi mednarodnih pravnih predpisov, ki so izhodišče za teoretsko analizo participacije otrok v družinski mediaciji, prikažem položaj otroka kot osrednjega subjekta v razveznih postopkih. ${ }^{4}$ Potem prikažem prednosti in dejavnike tveganja udeležbe otrok v mediaciji. Prikaz temelji na sekundarni analizi najvidnejše tuje teoretsko-empirične znanstvene literature. $V$ nadaljevanju $\mathrm{z}$ analitično metodo kritično ovrednotim teoretske in praktične ovire za zagotavljanje participativnih pravic otrok $\mathrm{v}$ mediaciji in podam konceptualne predloge za izboljšanje položaja otrok. $\mathrm{V}$ drugem delu s primerjalno in sintetično metodo ob upoštevanju različnih modelov participacije otrok razvijem koncept implementacije vključevanja otrok v mediacijo, ki je prilagojen slovenskemu normativnemu okviru in njegovim posebnostim. ${ }^{5}$ To je prispevek k teoretski utemeljitvi participacije otrok v mediaciji, s poudarkom na novem, večperspektivnem pogledu.

\section{Teoretska izhodišča za zagotavljanje participativnih pravic otrok v razvezni mediaciji}

Otroci so bili, tradicionalno gledano, nevidni in pasivni člani družine ter $\mathrm{v}$ številnih pogledih povsem izključeni iz družinskega diskurzivnega prostora (Saposnek, 2004, str. 156; Parkinson in Cashmore, 2012). 0 koristi otrok po razvezi staršev se je odločalo v odraslocentrični sferi, se pravi, da se je mnenje otrok uveljavljalo samo prek odraslih. Neupoštevanje otroka se je utemeljevalo zlasti z otrokovo nezrelostjo, nekompetentnostjo, pomanjkanjem izkušenj in razumevanjem otroka kot nemočnega, ranljivega in potrebnega zaščite, ki zato ne more uveljavljati svojih pravic (Rutar, 2013, str. 57; Tisdall, 2016).

Za sodobno otroško pravo pa je značilen »prenos težišča od varstva otroka na varstvo njegovih pravic« (Šelih, 2015, str. 12). Pri tem se je s sprejetjem mednarodnih dokumentov s področja otrokovih pravic in razvojem novejših konceptov o otroštvu izoblikovala nova podoba otroka, podoba otroka kot subjekta participativnih pravic (Lundy, 2007; Percy Smith in Thomas, 2010; Kodelja, 2015). Otrok vse bolj postaja prepoznan kot avtonomno in kom-

4 Pri tem se sklicujem na Konvencijo ZN o otrokovih pravicah (1990) in Zakon o ratifikaciji Evropske konvencije o uresničevanju otrokovih pravic (1999).

5 Pri tem se sklicujem na Zakon o mediaciji v civilnih in gospodarskih zadevah (2008), Družinski zakonik (2017), Zakon o varuhu človekovih pravic (2017), Splošni akt o načinu izvajanja zagovorništva otrok, organizaciji zagovorništva, vključitvi otroka v zagovorništvo ter nalogah, sestavi in načinu dela strokovnega sveta (2018), Zakon o nepravdnem postopku (2019) in Pravilnik o izvajanju mediacije po Družinskem zakoniku (2019). 
petentno bitje $\mathrm{z}$ integriteto ter predvsem kot aktiven soustvarjalec svojega življenja, zmožen izražanja samega sebe (Allison, 2009; Rutar, 2013, str. 64).

Po 12. členu Konvencije ZN o otrokovih pravicah (1990) so države pogodbenice dolžne otroku, ki je sposoben oblikovati svoje mnenje, zagotoviti pravico do svobodnega izražanja v vseh zadevah, o tehtnosti izraženih mnenj pa se presoja v skladu z otrokovo starostjo in zrelostjo. Za ta namen ima otrok še posebej možnost zaslišanja $v$ kateremkoli sodnem ali upravnem postopku $\mathrm{v}$ zvezi z njim, bodisi neposredno bodisi prek zastopnika ali ustreznega organa, na način, ki je v skladu s procesnimi pravili notranje zakonodaje. Odbor za otrokove pravice Združenih narodov (2009) je izrecno poudaril, da se pravica do participacije, ki jo zagotavlja 12. člen Konvencije ZN o otrokovih pravicah nanaša tudi na mediacijski postopek ob razvezi. Tudi Evropska konvencija o uresničevanju otrokovih pravic (1999), katere cilj je spodbujati otrokove procesne pravice zlasti v postopkih družinskega prava in mediacije, v 3. členu določa, da so države pogodbenice otrokom dolžne zagotoviti pravico do izražanja lastnega mnenja v postopku in pravico do obveščanja.

Vsebina obeh mednarodnih konvencij s področja otrokovih pravic se kaže v leta 2017 sprejetem Družinskem zakoniku, ki na normativni ravni izboljšuje položaj otrok tudi v mediacijskem postopku. Prvi odstavek 210. člena namreč določa, da mediator lahko v mediacijo vključi otroka, ki je sposoben razumeti pomen in posledice mediacije, če oceni, da je to otroku v korist. S tem daje mediatorju oprijemljivejšo podlago za odločitev o neposredni vključitvi otroka $\mathrm{v}$ mediacijo ob razvezi.

\section{Prednosti in tveganja neposrednega vključevanja otrok v mediacijo}

$\mathrm{V}$ eni najvidnejših tujih empiričnih študij, $v$ kateri so bili otroci neposredno vključeni v postopke ob razvezi staršev, so ti povedali, da je njihova vključitev pomembna, ker se sprejemajo odločitve o njihovem življenju in ker bodo prav oni s temi odločitvami živeli (Parkinson in Cashmore, 2012, str. 64-67). Otroci navajajo ključni prednosti vključitve otrok v proces razveze staršev: prva prednost je, da so pripoznani, upoštevani in slišani, druga pa, da s svojo participacijo pripomorejo k boljšim končnim sporazumom. Participacija otrokom pomeni priložnost, da se pogovorijo o različnih možnostih izbire, kot na primer, kako preživeti čas s starši, medtem ko si ne želijo, da bi morali izbrati med obema od njih (Birnbaum, 2009, str. 2; Parkinson in Cashmore, 2012, str. 67-68). Otroci v neki drugi empirični študiji navajajo tudi, da je ena od prednosti, ki jo ponuja participacija v mediaciji, učenje, kako sprejeti dobre odločitve, hkrati pa svojo udeležbo vidijo kot pomoč staršem, da bolje razumejo svoje otroke (Graham in Fitzgerald, 2010, str. 55). Goldson (2006, str. 11-12) pa je v študiji ugotovila, da so otroci zaznali, da je vključitev v mediacijo pripomogla k izboljšanju komunikacije med njimi in starši, zato so lahko preveli aktivnejšo vlogo pri prestrukturiranju družinskega življenja in odnosov po razvezi staršev.

Starši otrok, vključenih v mediacijo, so poročali, da ima udeležba otrok pomemben vpliv tudi na starše, ker se je povečalo njihovo zavedanje o vplivu konflikta na otroke (Goldson, 2006, str. 14-16). Starši vidijo mediacijo kot 
priložnost, da se otroci lahko prosto izrazijo in pogovorijo o svojem doživljanju z nevtralnim sogovornikom, ki jih razume ter jim pomaga zmanjšati strah in tesnobo (Graham in Fitzgerald, 2010, str. 55-56).

Vključevanje otrok v mediacijo pa prinaša tudi določena tveganja. Strokovnjaki menijo, da starši veliko teže sprejemajo skupne odločitve o otrocih, kadar so v medsebojnem konfliktu, vendar to ne sme biti razlog, da odgovornost za odločanje prepustijo otrokom, ker jim s tem naložijo preveliko breme. Participacija otrok v mediaciji lahko poveča konflikt lojalnosti oziroma otrokovo razdvojenost glede zvestobe do staršev, zato od otrok ne smemo zahtevati, da se morajo odločiti za enega od staršev. Nekateri otroci si želijo ugoditi staršem, zato obstaja tveganje, da je njihov avtentični in resnični glas zastrt z besedami in dejanji staršev (Warshak, 2003, str. 375).

Mediator mora znati prepoznati subtilno mejo med spoštovanjem pravice otroka do participacije in zlorabo otrokovega mnenja za osebne interese in legitimacijo lastnih stališč staršev (Guggenheim, 2005; Ewing, Hunter, Barlow in Smithson, 2015, str. 38). Pretirano pripisovanje pomembnosti izjave otroka in retorika o otrokovih pravicah sta v nekaterih primerih lahko pokazatelja, da se za altruistično podobo staršev skriva njihova nezmožnost sprejemati odločitve ali celo psihološka manipulacija z otrokom. Že omenjena empirična študija je pokazala, da pri vključevanju otrok v mediacijo obstaja tveganje, da starši ne bi znali konstruktivno sprejeti informacij, ki bi jih od strokovnjaka (mediatorja, zagovornika otrok) prejeli o počutju in željah njihovih otrok, to pa bi lahko negativno vplivalo na nadaljnji odnos z otrokom. Nekatera tveganja pri vključevanju otrok v mediacijo so povezana $\mathrm{z}$ neustrezno izvedbo mediacijskega procesa: pomanjkljiva informiranost staršev in otrok o namenu vključitve otrok v mediacijo, odsotnost povratne informacije otrokom o tem, kako je njihova soudeležba pripomogla $h$ končnim odločitvam, ter nezadovoljiva mediatorjeva podpora staršem in otrokom v procesu (Graham in Fitzgerald, 2010, str. 55-56).

\section{Konceptualno-teoretski premisleki o izboljšanju položaja otrok v družinski mediaciji}

Z normativno ureditvijo družinske mediacije v Družinskem zakoniku kot dodatne oblike pomoči družinam si država prizadeva spodbuditi uporabo mediacije in torej povečanje sporazumnih razvez. Ključna prednost mediacije je postopkovna avtonomija strank, ki temelji na načelu avtonomije strank. Ker je stopnja avtonomije staršev v mediacijskem postopku precej večja kot v sodnem postopku, se lahko prosto sporazumejo o pravilih in poteku postopka ${ }^{6}$ ter $\mathrm{z}$ lastno aktivnostjo pripomorejo k sporazumnim rešitvam, ki so bolj prilagojene njihovim interesom. V svojih dogovorih lahko uporabijo precej širši spekter

6 Kljub temu obstaja nekaj splošnih temeljnih načel družinske mediacije, na katera udeleženci ne morejo vplivati: načela prostovoljnosti, zaupnosti, nepristranskosti mediatorja in največje koristi otrok (Ristin in Hajtnik, 2011, str. 79). Nekatera temeljna pravila mediacijskega postopka opredeljuje Zakon o mediaciji v civilnih in gospodarskih zadevah (2008) in veljajo tudi za mediacijo, ki se izvaja po Družinskem zakoniku. 
ureditev odnosov med družinskimi člani, zato obstaja tudi večja verjetnost, da bo rešitev spora trajna (Folberg, Milne in Salem, 2004; Ristin in Hajtnik, 2011).

Trenutni trend na področju vključevanja otrok v mediacijo kaže, da je načelo participacije otrok v mediaciji podrejeno načelu avtonomije strank. Ta se osredišča zlasti na krepitev moči ${ }^{7}$ in samoodločbo staršev v postopku (James, Haugen, Rantalaiho in Marples, 2010; Jambrek, 2014). V slovenski mediacijski praksi namreč prevladuje na otroka osredotočena mediacija (angl. child focused mediation), pri kateri sta v ospredju predvsem ureditev odnosa med staršema in izdelava načrta vzgoje, varstva ter stikov otrok s starši (Ewing, Hunter in Smithson, 2015). Mnenje otroka pri takem pristopu zastopajo samo starši. Čeprav se pristop osredotoča na otrokove največje koristi, obstaja možnost, da bodo starši na otroke zaradi lastne čustvene prizadetosti projicirali svoje želje in interese ter tako napačno predpostavljali želje, počutje in doživljanje otrok (Saposnek, 2004, str. 156; McIntosh in Long, 2006, str. 123-125).

Premik od sodnega reševanja družinskih sporov k alternativnemu lahko zato ob odsotnosti konceptualnih razmislekov o soudeležbi otrok v mediaciji pomeni odmik od upoštevanja otrokovega glasu v razveznem postopku. Po mojem mnenju je namreč ključno, da se raven varstva otrokovih (participativnih) pravic v mediaciji približa tisti, ki jo otroci lahko pričakujejo od formalnih postopkov ${ }^{8}$ (Odbor ministrov Sveta Evrope, 2010, tč. 26, str. 24). Ewing, Hunter, Barlow in Smithson (2015, str. 14) zato predlagajo, da se načelo avtonomije strank $v$ družinski mediaciji razširi na načelo avtonomije družine. Predlagana razširitev načela po mojem mnenju temelji na avtonomiji in možnosti samoodločanja družine kot socialnega sistema odnosov, v katerem družina kot celota vpliva na vsakega družinskega člana in v katerem njeni družinski člani medsebojno vplivajo drug na drugega.

Načelo avtonomije družine temelji na dialogu in sodelovanju med starši in otroki, to pa ne pomeni, da otrokom damo moč odločanja ali jih celo obremenimo z odgovornostjo za sprejete končne odločitve - to je odgovornost staršev kot nosilcev odločanja. ${ }^{9}$ Pomeni predvsem možnost za razvoj sposobnosti za pogajanje, ki ustvari prostor za enkratnost, soočenje in dogovor (L'Abate, 1994). Doktrina socialnega dela je v tem pogledu razvila pomemben koncept etike udeleženosti: socialni delavec (in mediator) omogoči izkušnjo etike participacije in skrbno ravna s prispevkom vsakega člana družine pri odkrivanju novih pomenov in oblikovanju dogovorov (Hoffmann, 1994). Tudi uporaba ekosistemskega modela družinske mediacije spodbuja mediatorja, da se pri vodenju osredotoča na družino kot celoto ter upošteva prispevek, poglede in interese celotne družine, ne le razhajajočih se staršev (Parkinson, 2011, str. 45).

7 Čeprav velja ustaljena praksa, da se starši mediacije udeležijo s svojim odvetnikom, ki jim med postopkom tudi svetuje, je določitev zagovornika otroku v procesu mediacije za zdaj redka praksa.

8 Primerjaj 45. in 96. člen Zakona o nepravdnem postopku (2019).

9 Otroke naj mediator vključi samo glede zadev, ki se nanj nanašajo (otrokova vzgoja, varstvo in stiki s starši ali drugimi osebami), ne pa tudi glede preživninskih oziroma premoženjskih zadev. 


\section{Prikaz implementacije koncepta neposredne vključitve otrok v razvezno mediacijo in nekaterih etičnih dilem ob tem}

Odločitev za vključitev otroka v mediacijo in potek vključitve otroka sta glede na slovensko normativno ureditev prepuščena prosti strokovni presoji posameznega mediatorja, zato se $\mathrm{v}$ praksi dogajajo razlike pri implementaciji otrokove pravice do participacije. K upoštevanju in zagotavljanju otrokovih participativnih pravic v mediacijskem postopku po mojem mnenju odločilno pripomoreta zlasti mediatorjev pristop in osebna zavezanost vrednotam, povezanih s pojmovanjem otroka kot subjekta oziroma nosilca lastnih pravic $\mathrm{v}$ postopku. Vendar pa se družinski mediatorji zaradi svojih lastnih etičnih dilem, pomanjkanja znanja s področja otrokovih pravic in strokovnih usmeritev na konkretni ravni lahko odzovejo z zadržki do sodelovanja otrok v mediaciji.

Glede na pomanjkanje nacionalnih usmeritev v slovenskem mediacijskem prostoru, se pojavlja jasna potreba po pripravi neobvezujočih smernic in etičnih standardov za izvajalce družinske mediacije, s pomočjo katerih bi se vzpostavil pregleden in strukturiran okvir oziroma koncept neposredne vključitve otrok v mediacijo (angl. child inclusive mediation). ${ }^{10} \mathrm{~V}$ nadaljevanju zato prikažem celovit koncept vključevanja otrok v mediacijo, razvit na podlagi obstoječih slovenskih standardov otrokovih (participativnih) pravic in različnih modelov participacije otrok. ${ }^{11}$ Predlagani koncept je prilagojen slovenskemu prostoru in normativni ureditvi mediacije.

Ugotavljam, da skrbno načrtovanje vključevanja otrok v mediacijski proces poteka v skupnem sodelovanju mediatorja, staršev in otrok ter je sestavljeno iz petih faz: (1) ocena primernosti vključitve otroka v mediacijo in priprava staršev na vključitev otroka v mediacijo; (2) seznanitev otroka z razvezo in njegovo pravico do participacije $v$ mediaciji ter priprava otroka na vključitev $v$ mediacijo; (3) vključitev otroka v mediacijo; (4) povratna informacija staršem in presoja otrokovega mnenja z vidika otrokovih koristi; (5) povratna informacija otroku o upoštevanju njegovega mnenja in doseženem končnem sporazumu.

\section{Ocena primernosti vključitve otroka v mediacijo in priprava staršev na vključitev otroka v mediacijo}

Mediator mora, upoštevaje korist posameznega otroka, presoditi, ali in kako bo otrok v mediacijo vključen. Ključno je, da mediator staršem predstavi namen in koristi participacije otrok ter se ukvarja z njihovimi morebitnimi zadržki do vključitve otrok. Študije namreč kažejo, da je soglasje oziroma privolitev staršev v sodelovanje otroka ena največjih ovir pri zagotavljanju otrokovega glasu v postopku (Lansdown, 2011, str. 84; Voice of the child, 2015, str. 31).

10 Takih smernic oziroma kodeksa ravnanja ni mogoče zaslediti v okviru slovenskih društev oziroma združenj mediatorjev (npr. Medios, Društvo mediatorjev Slovenije, Mediacijski center Skupnosti centrov za socialno delo).

11 Z leti so se razvili številni modeli participacije otrok: Hart's Ladder of Participation (1992), Shier's Pathways to Participation (2001), Lundy's Model (2007). Za aplikacijo 12. člena Konvencije ZN o otrokovih pravicah (1990) in implementacije participativnih pravic otrok je ključna avtorica Lansdown $(2001,2005,2011)$. 
Starši lahko pogovor otroka s strokovnjakom doživljajo kot poseg v avtonomijo družine in spodkopavanje njihove vloge nosilcev odločanja. Po drugi strani so nekateri starši do otrok zaščitniški in jih ne želijo vznemirjati ali pa se morda bojijo, kaj bo otrok strokovnjaku povedal. Včasih jih skrbi, da bi vključitev otrok $\mathrm{v}$ mediacijo prispevala k napačni predstavi otrok, kaj je $\mathrm{v}$ prihodnosti možno doseči (Lansdown, 2011, str. 84; Voice of the child, 2015, str. 31).

Družinski zakonik opredeljuje, da lahko mediator v mediacijo vključi otroka, ki je sposoben razumeti pomen in posledice mediacije, in če oceni, da je to otroku v korist. ${ }^{12}$ Slovenska zakonodaja ne pozna fiksno določene starostne omejitve za vključitev otrok v mediacijo, zato se otroku zgolj na podlagi njegove starosti ne bi smelo onemogočiti, da se izjasni.

Mediator mora pri oceni koristi po predhodnem posvetovanju s starši pretehtati različne vidike, ki lahko odločilno vplivajo na sàmo odločitev o vključitvi otrok v mediacijo in pozneje na nadaljnji potek vključitve otroka: otrokovo sposobnost razumeti pomen in posledice mediacije (otrok se zaveda narave mediacijskega procesa, svoje vloge in vloge staršev ter mediatorja $\mathrm{v}$ postopku); otrokovo razvojno fazo in njegovo čustveno stanje; morebitni pojav razvojnih motenj ali čustveno vedenjskih motenj pri otroku; zmožnost staršev, da otroke poslušajo, ter zmožnost, da prepoznajo in zadovoljijo potrebe otrok; ${ }^{13}$ raven konflikta $\mathrm{v}$ družini, način in vzorce dogovarjanja $\mathrm{v}$ družini; fazo razveze in fazo mediacijskega procesa, v katerem sta partnerja; prednosti in morebitna tveganja vključevanja otrok $\mathrm{v}$ mediacijo; trenutno sodelovanje otroka z drugimi sorodnimi strokovnjaki; verjetnost vključitve otroka v druge strokovno-svetovalne službe (npr. zagovorništvo otrok) (College of Mediators, 2019).

Tuje študije kažejo, da je vključitev otrok v mediacijo primerna, zlasti kadar: otrok želi biti vključen in je sposoben izraziti svoje poglede in želje; nastane kolizija interesov med otrokom in obema staršema; otrok vztraja pri določeni želji (npr. komu želi biti zaupan v vzgojo in varstvo), eden od staršev pa temu nasprotuje; starši se želijo seznaniti z doživljanjem otroka in vplivom, ki ga ima razveza nanj; starši različno doživljajo otrokove potrebe in hotenja ter jih želijo pri otroku neposredno preveriti; otrok vsakemu od staršev govori drugače; otrok potrebuje razbremenitev in krepitev moči (Saposnek, 2004; McIntosh, 2007; Roberts, 2008; Birnbaum, 2009).

Vključitev otroka $v$ mediacijo glede na izsledke tujih študij ni primerna, kadar: otrok ne želi biti vključen v mediacijo; so starši odkrito sovražni drug do drugega in do otroka ter zanj ne želijo sprejeti odgovornosti; se starši ne strinjajo z vključitvijo otrok v mediacijo oziroma s pravili mediacijskega procesa, ki vključuje otroke $^{14}$ (npr. zaupnost otrokove izjave); imajo starši duševne motnje in jih ne

12 Za vključitev otroka v mediacijo je potrebno kumulativno izpolnjevanje obeh predpostavk: sposobnosti otroka razumeti pomen in posledice mediacije ter da je vključitev $v$ otrokovo korist (Kraljić, 2019, str. 701).

13 Graham in Yasenik (2016) sta razvila štiristopenjski model vključevanja otrok v mediacijo; prispevek otroka na posamezni stopnji in način vključitve otroka temeljita tudi na oceni zmožnosti staršev prepoznati potrebe otrok ter na ocenjeni stopnji starševskega konflikta.

Starša se v dogovoru z mediatorjem zavežeta, da s svojimi sugestijami ne bosta vplivala na otroka in ga zasliševala o samem poteku pogovora z mediatorjem oziroma zagovornikom. 
zdravijo; otrok ne razume pomena in posledic mediacije oziroma je premajhen, da bi znal izraziti svoje želje in potrebe; bi starši ali mediator z vključitvijo otroka želeli razrešiti zastoj v mediacijskem postopku; bi vključitev pomenila stres ali pritisk na otroka (British Columbia, 2003; Saposnek, 2004; McIntosh, 2007; Birnbaum, 2009).

Mediator lahko doživlja etično dilemo, kadar starši ne želijo vključiti otroka, sam pa presodi, da bi bila udeležba otroka smiselna. Nekateri strokovnjaki menijo, da mora mediator otroku, ki izrazi željo po vključitvi, omogočiti možnost vključitve v mediacijo, tudi če starša ne soglašata z njegovo vključitvijo (Voice of the child, 2015, str. 41). Saposnek (2004, str. 162) takemu ravnanju mediatorja nasprotuje z utemeljitvijo, da vključitev otroka lahko povzroči stopnjevanje konflikta med staršema ali morebitno manipulacijo $\mathrm{z}$ otrokovim mnenjem.

\section{Seznanitev otroka z razvezo in njegovo pravico do participacije $v$ mediaciji ter priprava otroka na vključitev $v$ mediacijo}

Glede na oceno primernosti vključitve otroka v mediacijo je treba otroka seznaniti s samim postopkom mediacije in njegovo pravico do udeležbe $\mathrm{v}$ mediaciji. Prav upoštevanje procesne pravice otroka do obveščenosti je nujni pogoj za uveljavljanje pravice otroka do izražanja lastnega mnenja (Odbor za otrokove pravice Združenih narodov, 2009, tč. 25, str. 10; 2. in 3. člen Evropske konvencije o uresničevanju otrokovih pravic). Naloga mediatorja je, da spodbudi in opomni starše, da je za otroke koristno, da so o družinskem dogajanju obveščeni in da se z njimi posvetujejo (Priporočilo št. R, 1998, tč. 45). Starši lahko otroka obvestijo sami ali pa s pomočjo mediatorja, ki otroku napiše povabilo s pojasnitvijo namena in poteka mediacije ter ga seznani $\mathrm{z}$ njegovo pravico do izjave $\mathrm{v}$ postopku mediacije. Otroci morajo vedeti, da lahko sodelovanje tudi zavrnejo, njihovo odločitev pa je treba upoštevati (Parkinson, 2011, str. 153).

\section{Vključitev otroka v mediacijo}

Čeprav konsenza o najustreznejšem pristopu k vključevanju otrok v mediacijo med akademiki in strokovnjaki ni, je glede na tuje empirične študije jasno, da mediatorji najpogosteje uporabljajo dva pristopa. V obeh vključitev otrok uresničuje več ciljev: zagotavlja upoštevanje otrokove procesne pravice do izjave, omogoča raziskovanje otrokovega doživljanja razveze in trenutne družinske situacije, zaupna oseba povečuje moč otroka, vključitev otroka pa tudi varuje njegove največje koristi v postopku.

Pri prvem pristopu vodi pogovor z otrokom mediator, ki je pred tem vodil proces mediacije z njegovimi starši. Mediator navadno v enkratnem pogovoru z otrokom prenese mnenje otroka staršem in pozneje skrbi za varovanje njegovega glasu v mediacijskem procesu in končnih dogovorih (Saposnek, 2004; Voice of the child, 2015, str. 11). Novozelandska raziskava je pokazala, da navzočnost istega mediatorja celotnemu mediacijskemu procesu zagotavlja kontinuiteto. 
Otroci so povedali, da so se na srečanju z mediatorjem počutili varno, saj je prej že spoznal njihove starše in je tako lahko bolje razumel njihovo družino (Goldson, 2006, str. 13). Kraljić (2019, str. 686) opozori, da lahko vključitev otroka v mediacijo povzroči kolizijo dveh temeljnih mediacijskih načel, in sicer načela nepristranskosti mediatorja in načela varstva otrokovih največjih koristi. Zadnje se mora hierarhično dvigniti nad načelo nepristranskosti mediatorja, ki mora biti v razmerju do otroka pristranski, saj mora ves čas mediacije varovati največje otrokove koristi.

Mediatorji se odločajo za vključitev otrok v različnih fazah mediacije; proti koncu raziskovalne faze mediacije, da lahko mediator že zgodaj vključi informacijo, poglede, občutke, skrbi otrok v sam postopek dogovarjanj, ali občasno v samem procesu oziroma kadarkoli starša preideta na temo, ki bi se lahko hitro razjasnila po zaslugi otrokovega prispevka (Saposnek, 2004, str. 161; Graham in Fitzgerald, 2010, str. 59). Slovenska pravna teorija poudarja smiselnost vključitve otroka, ko starša že dosežeta okviren dogovor o varstvu in vzgoji ter stikih, saj mediator tako lažje ohrani položaj nepristranskosti. Otroka seznani z že oblikovanimi stališči staršev, nato pa pridobi njegovo mnenje. Starša svoja stališča uskladita z otrokovimi in na koncu sprejmeta sporazum, ki je v otrokovo največjo korist in je sprejemljiv za oba starša (Ristin in Hajtnik, 2011, str. 237; Klemenčič, 2019, str. 710; Kraljić, 2019, str. 702).

$S$ stališča varovanja mediatorjeve nepristranskosti ${ }^{15}$ in večje strokovne usposobljenosti za delo z otroki je po mojem mnenju primernejši pristop, pri katerem pogovor z otrokom izvede strokovnjak za otroke in mladostnike. Empirično najbolj podprta tuja raziskava o vključevanju otrok v mediacijo navaja, da imajo t. i. otroški svetovalci dvojno vlogo varuha otrokovih koristi: vlogo zagovornika otrokovega glasu in sogovornika staršev pri prepoznavanju potreb njihovih otrok $v$ času razveze. Nameni enkratnega pogovora z otrokom so: njegova razbremenitev, ocena psiholoških in socialnih značilnosti psihosocialnega funkcioniranja ter ocena potreb in hotenj otroka. Na željo staršev ostane otroški svetovalec navzoč tudi na nadaljnjih mediacijskih srečanjih $\mathrm{s}$ starši in $\mathrm{v}$ tem primeru skupaj z mediatorjem vodita mediacijski proces (McIntosh in Long 2006, str. 17-18; McIntosh, 2007).

Slovenska zakonodaja z institutom zagovorništva otrok (182. člen Družinskega zakonika) omogoča, da otrok v mediacijskem postopku izrazi svoje mnenje s pomočjo zagovornika, ki deluje v okviru Varuha človekovih pravic RS. ${ }^{16}$ Zagovornik otroka je spoštljiv, odgovoren zaveznik in zaupnik (ne pa tudi zastopnik) otroka, ki pomaga otroku, da izrazi svoje mnenje v vseh postopkih in zadevah, $v$ katerih je udeležen, ter mnenje otroka posreduje pristojnim organom in institucijam, ki odločajo o njegovih pravicah in koristih (drugi odstavek 25.a člena Zakona o Varuhu človekovih pravic, 2017). Zagovornik se

Mediator svojo nepristranskost težje ohranja v situaciji, ko oceni, da so pogledi otroka posledica pritiska ali vpliva katerega od staršev ali kadar sta starša v konfliktu glede posredovanega mnenja otroka. Lahko se zgodi, da mediator svojo nepristransko vlogo nadomesti z vlogo zagovornika otrok oziroma se identificira s stališči otroka in prek tega posredno s stališči enega od staršev (Roberts, 2008, str. 194; Parkinson, 2011, str. 151).

Izvajanja zagovorništva tu ne obravnavam, saj presega temo in obseg prispevka. 
v odnosu do staršev in mediatorja ne opredeljuje oziroma ne ocenjuje otrokovega mnenja in ne rešuje morebitnih sporov med staršema. ${ }^{17}$

Prednost zagovorništva v primerjavi z enkratnim pogovorom z mediatorjem je v večjem poudarku na psihosocialni podpori otroka in v kontinuiteti procesa, ki v povprečju obsega od sedem do osem srečanj z otrokom. ${ }^{18}$ Pri enkratnem pogovoru z otrokom namreč obstaja tveganje, da otrok, ki se prvič sreča s strokovnjakom, do njega nima vzpostavljenega odnosa, to pa mu preprečuje, da bi lahko izrazil resnična čustva in skrbi (Čižman, 2019).

Določitev zagovornika otroku je smiselna na začetku postopka mediacije z namenom sočasnega poteka mediacijskega in zagovorniškega procesa. Pobudo za imenovanje zagovornika lahko poda vsak. Če varuh oceni, da je pobuda utemeljena, pridobi soglasje obeh staršev ali zakonitih zastopnikov in določi zagovornika s seznama zagovornikov. Soglasje staršev ali zakonitih zastopnikov ni potrebno, če z imenovanjem zagovornika soglaša otrok, ki je že dopolnil 15 let (tretji odstavek 25.a člena Zakona o Varuhu človekovih pravic, 2017).

\section{Načela in smernice pogovora mediatorja z otrokom}

$\mathrm{V}$ nadaljevanju opisana načela in smernice pogovora $\mathrm{z}$ otrokom so podlaga za zagotavljanje za otroka prijaznega in varnega mediacijskega postopka. ${ }^{19}$ Poglavitna naloga mediatorja $\mathrm{v}$ delovnem odnosu $\mathrm{z}$ otrokom je »ustvariti odprt dialoški prostor za otroka, otroku omogočiti čas, potrpežljivost, da otrok pove, razloži« (Čačinovič Vogrinčič in Mešl, 2019, str. 105). Participacija otrok, ki temelji na spoštljivem dialogu med otrokom in mediatorjem, mora biti prilagojena otrokovim razvojnim zmožnostim in razumevanju (angl. evolving capacities) (Lansdown, 2005).

Pogovor z otrokom vselej poteka na ločenem srečanju z mediatorjem $\mathrm{v}$ sobi za pogovor, ki je za otroka prijazna in prijetna. Na začetku pogovora mediator otroka seznani z načeloma prostovoljnosti in zaupnosti. Še enkrat mora preveriti otrokovo željo po sodelovanju in ga seznaniti, da lahko iz procesa kadarkoli izstopi. Poudariti mora, če otrok ne bi želel, da bi bila katera od zaupanih informacij prenesena staršem, lahko na to ob koncu srečanja opozori, mediator pa je dolžan dogovor o zaupnosti upoštevati. Otrok je že vnaprej seznanjen, da zaupnost informacij ne bo mogoča, če bi mediator dobil

17 Glede na Koncept zagovorništva otrok (Varuh človekovih pravic, 2018) je zagovornik osredotočen na stike z otrokom, se pravi, da mediator, ki vodi mediacijo, ne more biti hkrati tudi imenovan za zagovornika otroku.

Pravilnik o izvajanju mediacije po Družinskem zakoniku (2019, 32. člen) določa, da se mediacija konča po izvedbi največ petih srečanj v skupnem trajanju do deset ur oziroma po poteku treh mesecev od prvega srečanja. Načelo ekonomičnosti postopka mediacije, ki se kaže v časovni omejitvi postopka, zato pomeni tudi omejitev števila srečanj mediatorja z otrokom. Če pa je otrok vključen v zagovorništvo, časovno omejen obseg trajanja mediacije ne bi smel biti razlog za pritisk k čimprejšnjemu koncu zagovorniškega procesa.

Mediatorji, ki delujejo na področju socialnega varstva, se lahko pri vključevanju otroka v mediacijo oprejo na socialnodelovni koncept delovnega odnosa, saj je dober okvir za varovanje otrokovega glasu v procesu mediacije. Več o konceptu delovnega odnosa in smernicah za delo z otrokom v: Kodele in Mešl (2013). 
občutek, da je ogrožena njegova varnost. ${ }^{20}$ Naloga mediatorja je, da otroka razbremeni vsakršnega pritiska glede odgovornosti za končne dogovore in otroku pojasni, da njegovo mnenje ne bo nujno vplivalo na končno odločitev staršev. Koristno je, da mediator otroka razbremeni s pojasnilom, da lahko svojo izjavo oziroma želje v prihodnosti tudi spremeni, saj se navadno življenjske okoliščine, vrednote in hotenja med odraščanjem spreminjajo.

Priporočljivo je, da je mediator v pogovoru z otrokom odprt in se zaveda svojega vpliva, ki ga vnaša v pogovor, svojih osebnih vrednot, življenjskih izkušenj, izobrazbe in vpliva staršev otroka. Pomembno je, da otroku zagotovi čustveno podporo in ga razbremeni občutka krivde in odgovornosti. Pri tem lahko uporabi tehniki aktivnega poslušanja in povzemanja ter uporablja otrokov osebni jezik, a se izogiba terminologije in žargona. Mediator od otroka ne zahteva, da govori o stvareh, o katerih ne želi govoriti, predvsem pa je pomembno, da otroka nikoli ne pušča z občutkom neuspeha, ker ne želi ali ne zmore odgovoriti na vprašanje. Poglavitno je, da se mediator izogiba sugestivnim in direktnim vprašanjem, ki bi otroka napeljevala na odgovore, s katerimi bi moral izražati preference do staršev in izrecno izbirati, kaj si želi (Brown, 1995; Williams in Helland, 2007).

$\mathrm{S}$ pomočjo različnih tehnik in metod se mediator $\mathrm{z}$ otrokom pogovori o njegovi trenutni navezanosti na starše in njegovem doživljanju vsakega od staršev; o odnosu otroka s starši pred razvezo; vplivu razveze na otrokovo trenutno doživljanje staršev; otrokovih željah glede ureditve stikov ter vzgoje in varstva ter o njegovih specifičnih potrebah (McIntosh, 2007). Srečanje se navadno konča $\mathrm{z}$ izjavo otroka, $\mathrm{s}$ katero izpove svoje poglede in stališča glede razveze staršev, svoje spoprijemanje s trenutno družinsko situacijo ter potrebe in želje za prihodnost.

Pomembno pa je, da se starši zavedajo omejitev, ki jih prinaša vključevanje otrok v mediacijo, in sprejmejo, da morda ne bodo prejeli povratnih informacij od otroka, če se bo ta tako odločil. Mediator se v sklepni fazi z otrokom pogovori o možnosti nadaljnjega srečanja z namenom povratne informacije o sprejetih končnih odločitvah, ki so jih sprejeli starši.

\section{Povratna informacija staršem in presoja otrokovega mnenja z vidika njegovih koristi}

$V$ tej fazi otrok staršem s pomočjo mediatorja oziroma zagovornika ${ }^{21}$ predstavi svoje trenutno doživljanje družinske situacije oziroma svoje želje in hotenja.

Mediator, ki izve, da je otrok ogrožen, je dolžan o tem obvestiti center za socialno delo (četrti odstavek 210. člena Družinskega zakonika).

21 Varuh človekovih pravic RS (2019) je sprejel stališče: če ima otrok zagovornika in sta starša vključena v mediacijo, se izjava otroka s soglasjem staršev in otroka pošlje tudi mediatorju. » $V$ dogovoru s starši, mediatorjem in otrokom lahko zagovornik otroka sam ali v spremstvu otroka predstavi mnenje otroka na enem od mediacijskih srečanj. Po mnenju Varuha človekovih pravic RS prisotnost zagovornika lahko pozitivno vpliva tudi na starša. Po nekaterih izkušnjah s sodišč lahko prisotnost zagovornika pripomore $k$ večji pripravljenosti staršev na sklenitev dogovora, ki je v korist otroka. (Jasna Vunduk, Varuh človekovih pravic RS, osebna komunikacija, 14. september 2020). 
Naloga mediatorja je, da vzpostavi odprt in varen prostor za pogovor, ki bo omogočil raziskovanje možnega prispevka otrokovega glasu h končnim dogovorom. Pri tem mediator otrokovemu mnenju oziroma izraženim željam ne pripisuje pomena, jih ne interpretira ali ocenjuje.

Mediator starše na srečanju brez otrokove navzočnosti spodbudi, da pri presoji izraženih mnenj upoštevajo trajanje in konsistentnost otrokove volje, jasnost, intenzivnost oziroma moč volje in praktične vidike otrokove volje. Na izraženo željo otroka lahko vpliva več dejavnikov, ki jih je pri presoji treba upoštevati: njegova starost, intelektualna, čustvena in socialna zrelost, odnos s sorojenci, starševske spretnosti, slog vzgoje in reševanje sporov, osebnost starša ipd. (Dobnik Renko in Hribar, 2018, str. 171-172).

Sklicevanje na starost in zrelost kot na dejavnika pri presoji otrokovega mnenja je kompleksni vidik 12. člena Konvencije $Z N$ o otrokovih pravicah (1990). Prepričanje, da je zrelost otroka neposredno povezana z njegovo biološko starostjo, se lahko kaže v diskriminaciji otrok na podlagi starosti. To za posameznega otroka pomeni, da nosilci odločanja zavrnejo želje mlajših otrok zgolj na podlagi tega, da so otroci premajhni, ne da bi odločitev dodatno utemeljili (Lansdown, 2005, str. 28; Daly, 2018). Lansdown (2001, str. 3) utemeljuje, da se kompetence ne razvijajo uniformirano v skladu s togo zamišljenimi razvojnimi stopnjami, zato morajo odrasli pri presoji otrokovega mnenja upoštevati, da na zmožnosti razumevanja otroka vplivajo tudi socialni kontekst, narava odločitev, življenjske izkušnje otrok in stopnja podpore odraslih. Pomembno je, da se odrasli zavedajo, da je presoja otrokovega mnenja odvisna tudi od njihove interpretacije, ki se največkrat kaže predvsem kot konstrukt položaja odraslosti (Kodele in Mešl, 2013, str. 65; Rutar, 2013, str. 78).

Otrokova želja in njegova korist nista sopomenki, otrokova volja je namreč le eno od meril pri presojanju njegove koristi (Čujovič, 2019, str. 73). Glede na 7. člen Družinskega zakonika morajo v vseh dejavnostih v zvezi z otrokom predvsem starši skrbeti za njegovo korist (Novak, 2017, str. 43). To velja zlasti za postopek mediacije, pri katerem starši kot formalni udeleženci mediacijskega postopka ob pomoči mediatorja avtonomno sooblikujejo postopek in sprejmejo končni sporazum. ${ }^{22}$ Pomembno je, da starši pri izdelavi načrta vzgoje in varstva ter stikov razmislijo, pri katerem od staršev bo imel otrok več podpore pri graditvi osebnosti (načelo pospeševanja otrokovega razvoja) in pri katerem od staršev bo imel več možnosti ohraniti obstoječa razmerja zunanjega sveta (načelo kontinuitete vzgoje in varstva). Razmisliti morajo tudi o potrebah otroka, o navezanosti in pripadnosti otroka enemu ali drugemu, razvojnih zmožnostih otrok pri vsakem od staršev, o svojih osebnostnih lastnostih in vzgojnih sposobnostih ter ne nazadnje tudi o celotnem kontekstu življenjske situacije (socialnem, ekonomskem in kulturnem okolju) (Novak, 2017, str. 202-203; Čujovič, 2019, str. 66-67).

Če želita starša skleniti dogovor, ki objektivno nasprotuje koristi otroka, je mediator dolžan na to opozoriti, lahko pa tudi odkloni sodelovanje v media-

Dispozicija udeležencev je v družinski mediaciji omejena, saj velja načelo zakonitosti, kar pomeni, da mora biti sporazum v skladu z družinskimi materialnopravnimi predpisi (starš se na primer ne more odpovedati obveznosti preživljanja). 
ciji, če oceni, da je otrokova korist huje ogrožena (Ristin in Hajtnik, 2011, str. 236). Starše mora mediator seznaniti, da sodnik vselej objektivno preveri, ali je sporazum, ki so ga dosegli, res v korist otrok (Čujovič, 2019, str. 74). Sodišče predlog staršev zavrne, če ni v otrokovo korist (drugi odstavek 138. člena; četrti odstavek 141. člena, tretji odstavek 142. člena Družinskega zakonika).

\section{Povratna informacija otroku o upoštevanju njegovega mnenja in doseženem končnem sporazumu}

V sklepni fazi mediacije mediator ali starši otroka seznanijo z dogovori, ki so jih na podlagi njegove vključitve v mediacijo sklenili njegovi starši (McIntosh in Long, 2006, str. 17-18; Odbor za otrokove pravice Združenih narodov, 2009, str. 13, tč. 45). Faza je pomemben vidik dialoga med otrokom in odraslimi, ker se otroka seznani z informacijo, koliko so starši njegovo mnenje pri končni odločitvi upoštevali. Starši lahko v končnem sporazumu tudi utemeljijo, kako so upoštevali otrokovo izjavo. Kadar obstaja utemeljen razlog, da odrasli otrokovih mnenj pri končni odločitvi ne upoštevajo, je ključno, da otroku podajo povratno informacijo z razlago o tem, zakaj je bila sprejeta drugačna odločitev, in mu nato pomagajo iskati alternativne načine, da uresniči svoje želje (Shier, 2001, str. 113).

Če se mediacija ne konča s sporazumom in se reševanje spora nadaljuje v nepravdnem postopku na sodišču, menim, da sodišče lahko s soglasjem otroka njegovo mnenje, pridobljeno $v$ mediacijskem procesu, uporabi tudi $v$ nadaljnjem postopku. Cilj uporabe mnenja v nadaljnjem sodnem postopku je spoštovanje dostojanstva otrok, tako da se čim bolj omeji število zaslišanj otrok, in sicer z namenom preprečevanja dodatnega stresa. ${ }^{23}$

\section{Sklepne misli}

S prispevkom želim dopolniti primerjalno teoretsko-empirično raziskovanje varstva pravice otroka do participacije v mediaciji in skušam odgovoriti na nekatera konceptualna vprašanja in etične dileme, ki se pojavljajo na področju mediacijske doktrine.

Ugotavljam, da se v mednarodni in slovenski zakonodaji vse bolj uveljavlja stališče, da odločitve, ki se sprejemajo o prihodnosti otrok ob razvezi njihovih staršev, ne morejo biti sprejete brez upoštevanja načela participacije otrok, ki otrokom zagotavlja pravico do svobodnega izražanja lastnega mnenja ter v skladu z njihovo zrelostjo in starostjo tudi ustrezno presojo tega mnenja.

23 V zvezi s pridobljenim mnenjem otroka v okviru družinske mediacije in njegovi uporabi v nadaljnjem postopku je smiselna uporaba Zakona o mediaciji v civilnih in gospodarskih zadevah (2008) (Weber, 2019, str. 22). Zakon o mediaciji v civilnih in gospodarskih zadevah (2008) v tretjem odstavku 12. člena določa izjemo od načela zaupnosti v mediacijskem postopku v primeru zaščite interesov otrok, ki bi lahko kot eksplicitna izjema po tem zakonu dopuščala uporabo že pridobljenega mnenja v mediaciji tudi v nadaljnjem sodnem postopku. Zagovornik otroka oziroma sodnik na neformalnem pogovoru z otrokom bi moral po mojem mnenju obvezno pri otroku še enkrat preveriti, ali njegovo podano mnenje še ustreza trenutnim okoliščinam in njegovim željam. 
Temeljno sporočilo prispevka je, da mora mediacijski postopek ob razvezi kljub svoji neformalni naravi, ki temelji na načelu avtonomije strank, zagotoviti primerljivo raven varstva pravice otrok do participacije, kot ga lahko otroci pričakujejo od formalnih družinskopravnih postopkov. Učinkovita implementacija otrokovih participativnih pravic v družinski mediaciji zato zahteva paradigmatski premik od odraslocentričnega pristopa k družinskocentričnemu, ki temelji na načelu avtonomije družine. Novo predlagano načelo avtonomije družine odpira prostor tudi za otroka in ga prepoznava kot kompetentnega sogovornika odraslih.

Participacija otrok je predvsem pravica otrok, hkrati pa je zagotavljanje ustreznih mehanizmov za inkluzivno in za otroke prijazno participacijo pravno zavezujoča dolžnost odraslih. Pomemben korak k utrditvi položaja otrok v mediaciji je bil v slovenskem prostoru dosežen leta 2017 s sprejetjem Družinskega zakonika, saj mediatorju omogoča vključitev otroka v mediacijo. Odločitev za udeležbo otroka v mediacijo in sam potek vključitve otroka sta v slovenski zakonodaji prepuščena diskreciji posameznega mediatorja, zato ugotavljam, da je za kakovostno delo mediatorjev nujno oblikovanje celovitih nacionalnih smernic in etičnih standardov v obliki kodeksa ravnanja za družinske mediatorje, ki bi na makroravni podprl in usmeril delovanje mediatorjev. V Sloveniji pogrešam tudi natančnejše standarde strokovne usposobljenosti družinskih mediatorjev, ki bi na nacionalni ravni določali obvezno raven zahtevanih spretnosti in znanj za vključitev otrok v mediacijo. ${ }^{24}$

Praksa neposrednega vključevanja otrok v mediacijo je predvsem odgovorna in zahtevna naloga, ki prinaša tudi določena tveganja, zato h kakovostnemu strokovnemu delu z otroki prispeva tudi vključenost mediatorja $\mathrm{v}$ supervizorski proces. Kot poudarita Čačinovič Vogrinčič in Mešl (2019, str. 105), v procesih podpore in pomoči velikokrat manjka prav glas otroka, zato se moramo strokovnjaki naučiti, kako ga bomo spodbudili in varovali.

\section{Viri}

Allison, J. (2009). Agency. V J. Qvortrup, W. A. Corsaro, \& M. S. Honig (ur.), The Palgrave handbook of childhood studies (str. 34- 45). New York: Palgrave Macmillan.

Andrejč, A. (2014). Negativni učinki razveze staršev na otroke in mladostnike: dejavniki tveganja in varovalni dejavniki. Socialno delo, 53(1), 25-41.

Birnbaum, R. (2009). The voice of the child in separation/divorce mediation and other alternative dispute resolution processes: a Literature review. Canada: Department of Justice

Družinski zakonik (2017) in Pravilnik o izvajanju mediacije po Družinskem zakoniku (2019) ne navajata posebnih pogojev za mediatorje, ki želijo v mediacijo vključiti otroka. Prvi odstavek 207. člena Družinskega zakonika določa le splošni pogoj, da mora imeti mediator najmanj izobrazbo, pridobljeno po visokošolskem študijskem programu. Glede pogojev izobraževanja za družinske mediatorje 19. člen Pravilnika določa, da izobraževanje obsega vsaj 40 pedagoških ur. Priloga Pravilnika zelo ohlapno navede le tematike, ki naj jih izobraževanje obsega: posebnosti mediacije $v$ družinskih sporih, predpisi s področja družinskih razmerij in mediacije v družinskih sporih, etika idr. Primer dobre prakse so Standardi Krovnega združenja za družinsko mediacijo (Anglija in Wales), ki določajo, da morajo mediatorji, ki želijo v mediacijo vključiti otroke, v dodatnem 40-urnem usposabljanju pridobiti določeno znanje in spretnosti za delo z otroki v mediaciji (Family Mediation Council, 2018). 
Canada. Pridobljeno 2. 6. 2020 s https://www.justice.gc.ca/eng/rp-pr/fl-lf/divorce/vcsdm-pvem/index.html

British Columbia (2003). The involvement of children in divorce and custody mediation: a literature review. Pridobljeno 5. 5. 2020 s https://www2.gov.bc.ca/assets/gov/law-crime-and-justice/about-bc-justice-system/justice-services-branch/fjsd/mediation.pdf

Brown, C. (1995). Involving childrenindecisionmaking withoutmakingthemthedecisionmakers. Pridobljeno5.5.2020shttp://www.familycourt.gov.au/wps/wcm/connect/a6ce5a3a-e6b1-4725-8ddd-6c1e79da3c26/Involving_children_in_decisions.pdf?MOD=AJPERES\&CONVERT_ TO=url\&CACHEID=a6ce5a3a-e6b1-4725-8ddd-6c1e79da3c26.

College of Mediators (2019). The voice of children \& young people in mediation policy and best practice guidelines. Združeno kraljevstvo: College of Mediators.

Čačinovič Vogrinčič, G. (2010). Soustvarjanje pomoči v jeziku socialnega dela. Socialno delo, 49(4), 239-245.

Čačinovič Vogrinčič, G., \& Mešl, N. (2019). Socialno delo z družino: soustvarjanje želenih izidov in družinske razvidnosti. Ljubljana: Univerza v Ljubljani, Fakulteta za socialno delo.

Čižman, G. (2019). Določanje koristi otroka v postopkih zaščite na centru za socialno delo. V V. Leskovšek, T. Kodele, \& N. Mešl (ur.), Zaščita otrok pred nasiljem in zanemarjanjem v Sloveniji (str. 60-82). Ljubljana: Univerza v Ljubljani, Fakulteta za socialno delo.

Čujovič, M. (2019). 7. člen. V B. Novak (ur.), Komentar Družinskega zakonika (str. 58-76). Ljubljana: Uradni list Republike Slovenije.

Daly, A. (2018). No weight for » due weight «? A children's autonomy principle in best interest proceedings. The International Journal of Children's Rights, 26(1), 61-92.

Dobnik Renko, B. \& Hribar, N. (2018). Delo sodnih izvedencev kliničnopsihološke stroke v družinskopravnih postopkih. Bilten, 39(2), 161-177.

Družinski zakonik (2017). Ur. l. RS, št. 15/2017, 21/2018 - ZNOrg, 22/2019 in 67/2019 - ZMatR-C.

Ewing, J., Hunter, R., Barlow, A., \& Smithson, J. (2015). Children's voices: centre-stage or sidelined in out-of-court dispute resolution in England and Wales? Child and Family Law Quarterly, 27(1), 43-61.

Family Mediation Council (2018). Standards framework changes for CIM, May 2018. Pridobljeno 1.7. 2020 s https://www.familymediationcouncil.org.uk/wp-content/uploads/2018/05/ Standards-Framework-changes-for-CIM-May-2018.pdf

Folberg, J., Milne, A. L., \& Salem P. (ur.). (2004). Divorce and family mediation (models, techniques and applications). New York: The Guildford Press.

Goldson, J. (2006). Hello I'm a voice, let me talk: child-inclusive mediation in family separation. Auckland: Centre for Child and Family Policy Research, Auckland University. Pridobljeno 30. 5. 2020 s http://thefamilymatterscentre.co.nz/wp-content/uploads/2015/08/Hello_Im_A_Voice.pdf

Graham, A., \& Fitzgerald, R. (2010). Exploring the promises and possibilities for children's participation in family relationship centres. Family Matters, 84, 53-60.

Graham, J. M., \& Yasenik, L. A. (2016). The continuum of including children in ADR process: a children-centred continuum model. Family Court Review, 54(21), 186-202.

Guggenheim, M. (2005). What's wrong with children's rights. Združene države Amerike: Harvard University Press.

Hoffmann, L. (1994). A reflexive stance for family therapy. V S. McNamee \& K. V. Gergen (ur.), Therapy as social construction. London: Sage.

Jambrek, E. (2014). Glas otroka v družinski mediaciji ob razvezi (Diplomsko delo). Ljubljana: Univerza v Ljubljani, Fakulteta za socialno delo.

James, A. L., Haugen, D. G. M., Rantalaiho, M., \& Marples, M. (2010). The voice of the child in family mediation: Norway and England. International Journal of Chilldren's Rights, 18, 313-333.

Jensen, A. M. (2009). Plurlization of family forms. V J. Qvortrup, W. A. Corsaro, \& M. S. Honig (ur.), The Palgrave handbook of childhood studies (str. 140-155). New York: Palgrave Macmillan. 
Klemenčič, A. (2019). 205. člen. V B. Novak (ur.), Komentar Družinskega zakonika (str. 684716). Ljubljana: Uradni list Republike Slovenije.

Kodele, T., \& Mešl, N. (ur.) (2013). Otrokov glas v procesu učenja in pomoči: priročnik za vrtce, šole in starše. Ljubljana: Zavod Republike Slovenije za šolstvo.

Kodelja, Z. (2015). Participativne pravice otrok: pravica do glasu, svobode misli, vere, združevanja. V A. Šelih, \& K. Filipčič (ur.), Otrokove pravice v Sloveniji: sedanje stanje in izzivi za prihodnost (str. 99-115). Ljubljana: Slovenska akademija znanosti in umetnosti.

Konvencija ZN o otrokovih pravicah (1990). Akt o notifikaciji nasledstva glede konvencij Organizacije združenih narodov in konvencij, sprejetih v Mednarodni agenciji za atomsko energijo. Ur. l. RS - Mednarodne pogodbe, št. 9/92, 3/93, 9/93, 5/99, 9/08, 13/11 in 9/13; Ur. l. SFRJ - Mednarodne pogodbe, št. 15/90.

Kraljić, S. (2019). Družinski zakonik s komentarjem. Maribor: Poslovna založba MB.

L'Abate, L. (1994). Family evaluation. Thousands Oaks: Sage.

Lansdown, G. (2001). Promoting children's participation in democratic decision-making. Florence: UNICEF Innocenti Research Centre.

Lansdown, G. (2005). The evolving capacities of the child. Italija: UNICEF: Innocenti Research Centre. Pridobljeno 28. 5. 2020 s https://www.unicef-irc.org/publications/pdf/evolving-eng.pdf

Lansdown, G. (2011). Every child's right to be heard: a resource guide on the UN Committee on the rights of the child General comment NO 12. Združeno kraljestvo: Save the Children UK. Pridobljeno 3. 5. 2020 s https://resourcecentre.savethechildren.net/node/5259/ pdf/5259.pdf

Lundy, L. (2007). "Voice" is not enough: conceptualizing Article 12 of the United Nations Convention on the Rights of the Child. British Educational Research Journal, 33(6), 927-942.

Mclntosh, J. (2007). Child inclusion as a principle and as evidence-based practice: applications to family law services and related sectors. Pridobljeno 15. 5. 2020 s https://aifs.gov.au/ cfca/publications/child-inclusion-principle-and-evidence-based-practic/section-1-mandate-child-inclusion

McIntosh, J., \& Long, C. M. (2006). Children beyond dispute: a prospective study of outcomes from child focused and child inclusive post-separation family dispute resolution. Final report. Canberra: Australian Government Attorney - General's Department. Pridobljeno 15. 5. 2020 s http://www.thelizlibrary.org/liz/McIntosh.pdf

Novak, B. (2017). Družinski zakonik z uvodnimi pojasnili. Ljubljana: Uradni list Republike Slovenije.

Odbor ministrov Sveta Evrope (2010). Smernice Odbora ministrov Sveta Evrope za otrokom prijazno pravosodje. Pridobljeno 14. 5. $2020 \mathrm{~s}$ http://spolna-zloraba.si/wp-content/uploads/2015/08/Smernice-Odbora-ministrov-Sveta-Evrope-za-otrokom-prijazno-pravosodje.pdf

Odbor za otrokove pravice Združenih narodov (2009). Splošni komentar št. 12 - Pravica otroka, da je slišan. Pridobljeno 15. 5. 2020 s https://www2.ohchr.org/english/bodies/crc/ docs/AdvanceVersions/CRC-C-GC-12.pdf

Parkinson, L. (2011). Družinska mediacija. Ljubljana: Inštitut za mediacijo Concordia.

Parkinson, L. (2019). Wider perspectives in family mediation: an ecosystemic approach. Australian and New Zealand Journal of Family Therapy, 40, 62-73.

Parkinson, P., \& Cashmore, J. (2012). The voice of a child in family law disputes. United Kingdom: Oxford University Press.

Percy Smith, B., \& Thomas, N. (2010). A handbook of children's and young people's participation: perspectives from theory and practice. New York: Routledge.

Pravilnik o izvajanju mediacije po Družinskem zakoniku (2019). Ur. l. RS, št. 76/19.

Pravilnik o izvajanju predhodnega svetovanja (2019). Ur. l. RS, št. 21/19.

Priporočilo št. $R$ (1998). Poročilo št. $R$ (98) 1 Odbora ministrov Sveta Evrope državam članicam o družinski mediaciji (1998). Sprejel Odbor ministrov dne 21. januarja 1998 na 616. zase- 
danju ministrskih namestnikov. Pridobljeno 5. 5. 2020 s https://search.coe.int/cm/Pages/ result_details.aspx?ObjectID=09000016804ee220

Ristin, G., \& Hajtnik Z. (ur.) (2011). Mediacija v teoriji in praksi: veliki priročnik o mediaciji. Ljubljana: Društvo mediatorjev Slovenije.

Roberts, M. (2008). Mediation in family disputes: principles of practice. Hampshire: Ashgate Publishing.

Rutar, S. (2013). Poti do participacije otrok v vzgoji. Koper: Univerza na Primorskem, Znanstveno-raziskovalno središče, Univerzitetna založba Annales.

Saposnek, D. T. (2004). Working with children in mediation. V J. Folberg, A. L. Milne, \& P. Salem (ur.), Divorce and family mediation (models, techniques and applications) (str. 155179). New York: The Guildford Press.

Shier, H. (2001). Pathways to participation: opening, opportunities and obligations. Children \& Society, 15(2), 107-117. Pridobljeno 15. 5. 2020 s https://www.ipkl.gu.se/digitalAssets/1429/1429848_shier2001.pdf.

Splošni akt o načinu izvajanja zagovorništva otrok, organizaciji zagovorništva, vključitvi otroka v zagovorništvo ter nalogah, sestavi in načinu dela strokovnega sveta (2018). Ur. l. RS, št. 44/18 in 4/20.

Šelih, A. (2015). Konvencija OZN o otrokovih pravicah in današnji čas. V: Šelih, A., \& K. Filipčič, (ur.), Otrokove pravice v Sloveniji: sedanje stanje in izzivi za prihodnost (str. 10-22). Ljubljana: Slovenska akademija znanosti in umetnosti.

Švab, A. (2001). Družina: od modernosti k postmodernosti. Ljubljana: Znanstveno in publicistično središče.

Tisdall, E. K. M. (2016). Subjects with agency? Children's participation in family law proceedings. Journal of Social Welfare and Family Law, 38(4), 362-379.

Toš, N. (ur). (2016). Vrednote $v$ prehodu X. Slovensko javno mnenje 2010-2016. Ljubljana in Wien: Univerza v Ljubljani, Fakulteta za družbene vede, in IDV, CJMMK.

Varuh človekovih pravic RS (2018). Koncept zagovorništva otrok. Pridobljeno 25. 5. $2020 \mathrm{~s}$ https://www.varuh-rs.si/o-varuhu/organizacijske-enote-in-svet-varuha/zagovornistvo-otrok/levi-meni/koncept-zagovornistva-otrok/.

Varuh človekovih pravic RS (2019). Letno poročilo varuha človekovih pravic Republike Slovenije za leto 2019. Ljubljana: Varuh človekovih pravic RS.

Voice of the child (2015). Final report of the Voice of the Child Dispute Resolution Advisory Group. Pridobljeno 28. 5. 2020 s https://assets.publishing.service.gov.uk/government/ uploads/system/uploads/attachment_data/file/421005/voice-of-the-child-advisory-group-report.pdf

Warshak, R. A. (2003). Payoffs and pitfalls of listening to children. Family Relations, 52, 373384.

Weber, N. (2019). Otrokovo mnenje v družinski mediaciji. Pravna praksa, 38(37), 22-23.

Williams, S., \& Helland J. (2007). Hear the child interviews: Kelowna pilot evaluation. Victoria: International Institute for Child Rights and Development. Pridobljeno 28. 5. $2020 \mathrm{~s} \mathrm{http://}$ www.iicrd.org/sites/default/files/HearTheChildInterviewEvaluation.pdf

Zakon o mediaciji v civilnih in gospodarskih zadevah (2008). Ur. l. RS, št. 56/2008.

Zakon o nepravdnem postopku (2019). Ur. l. RS, št. 16/19.

Zakon o ratifikaciji Evropske konvencije o uresničevanju otrokovih pravic (1999). Ur. l. RS Mednarodne pogodbe, št. 26/99.

Zakon o varuhu človekovih pravic (2017). Ur. l. RS, št. 69/17. 